AGRICULTURE IN THE WEST INDIES.

THE third annual Agricultural Conference, under the presidentship of Dr. Morris, Commissioner of the Imperial Department of Agriculture for the West Indies, was held in the Legislative Chamber, Bridgetown, Barbados, on January 5. Besides Dr. Morris, the president of the Conference, and some fifty official, scientific, agricultural and educational representatives from the various West Indian colonies, there were present the Acting Governor, a large number of officials and representatives of the Legislature, and visitors.

After the usual preliminary formalities, Dr. Morris delivered his presidential address, which afforded a clear summary of the progress made by the Department of Agriculture for the preced ing year and enumerated the questions which this Conference would be invited to discuss. The work of the officers of the Department during the preceding year covered a wide range. In the domain of the sugar industry it comprised rescarches to improve the sugar cane, experiments to reduce the cost of cultivation, efforts to advance the erection of central factories and researches upon insect and fungnid diseases, including an ex. haustive investigation and monograph by the entomologist, Mr. H. Maxwell Lefroy, on the moth borer (Diatraea sac. charalis).

Besides the work of the Department on the cacao industry and the lime industry, an attempt had been made, with prospects of success, to establish the growing of early putatoes for the English market; a small but prumising onion industry had been estab. lished in Antigua, and there was every reason to believe that the fruit trade between Jamaica and the United Kingdom would receive an enormous impetus by the subsidising a direct fruit steamer service between the Mother Country and that Colony.

Agricultural education had occupied a large share of attention; the teachers of the elementary schoois of nearly all the colonies were being trained by courses of lectures and demonstrations to teach the elementary principles of agriculture in their schools; seven exhibitions, of value varying from $10 l$. to $75 l$. per annum, had been awarded to pupils from first grade (public) schools in the various islands which were tenable at Harrison College, where a two years' course in agricultural science was given by the science Departnent, Barbados. Agricultural in dustrial schools had been opened at St. Vincent and Dominica.

Nine botanic stations were now supported by Imperial funds and a large number of experimental stations had been instituted in the various colonies, where experiments were being systematically carried out on questions connected with the sugar cane and all the other products of the West Indies.

Agricultural shows had been successfully carried out in three of the islands under the auspices of the I. Cepartment, which had contributed $35 \mathrm{O} /$. in prizes and more than one liundred diplomas of merit.

The address concluded with some remarks upon the subject of the treatment of diseased plants, and upon the advisability of legislation with a view to prevent the introluction of plant disease into colonies from without, and to provide for the eradication of disease within the colonies.

The following papers were read during the Conference :-

Sugar Industry: Recent experiments with seedlings and other canes, by Prof. d'Albuquerque and Mr. J. R. Bovell (Barbacios), and a short history of seedling canes in Barbaclo;, by Mr. J. R. Bovell (Barbados), followed by a discussion in which representatives from all the colonies took part; cane farming in Trinidad, by Prof. Carmody (Trinidad) : insect pests of sugar cane, by Mr. II. Maxwell Lefroy, entomologis of the Department ; fungoid diseases of the sugar cane, by .Ir. Albert Howard (Barlsados).

Educational: Agricultural education and its place in general education, by Rev. Canon Simms (Jamaica); teaching the principles of agriculture in elementary schools, by the Hion. T Capper (Jamaica); results of ien years' experience with compul. sory enactments in the Leeward Islands, by Mr. C. M. Martin (Leeward Islands).

General:-Legislation to control bush fires, by Dr. II. Nicholls (Dominica); the treatment of soils in orchard cultiva tion in the tropics, by the Hon. Francis Watts (Leeward Islands); on rubber planting in the West Indies, by Mr. J. H. Ilart (Trinidad); pine-apple cultivation at Antigua, by the Hon. Francis Watts (Leeward Islands); the marine resources of the West Indies, by Dr. J. E. Duerden (Jamaica); beekeeping, by Mr. W. K. Morrison, the acting bee expert of the Department ; the cultivation of onions at Antigua, by $\mathrm{Mr}$. Wm. NO. I6 32 , VOL. 63$]$
Sands; zebra cattle in Trinidad, by Mr. J. H. Hart and Mr. C. W. Meaden ; artificial drying of cacao, by Mr. G. Whitfield Smith; and experiments on the treatment of insect pests in I 900 , by Mr. II. Naxwell Lefroy. These papers, together with the discussions that followed them, will be produced in the West Indian Bulletin, the official organ of the Imperial Agricultural Department for the West Indies.

The Chemical Section of the Conference, adjourned from the previous year, drew up a report dealing chiefly with uniformity of records in reports upon sugar cane experiments. The Educational Section held a meeting to consider matters connected with the teaching of agriculture in elementary and first grade schools, including the cumpilation of teachers' handbonks.

\section{J. P. D'A.Buqueroque.}

\section{NATIONAL ASPECTS OF SCIENTIFIC INVESTIGATION.}

$A \mathrm{~S}$ a rule, the recognition of scientific work by the State is the last matter with which men of science concern themselves. Their work is sufficient for them, and they are content with the results obtained, whether appreciated or not at the proper value to the commonwealth ; they are the victors, but they leave the spoils to others. Most true investigators are inspired by this unselfish sentiment, rather than by the desire for personal profit, and all they ask fur is the adequate provision of means for research. Even this request is not urged with the persistency necessary to produce effeci. It nutust be remembered that the general public, as well as the persons who have it in their power to encourage investigation by granting subsidies and extending other facilities, do not understand the fundamental importance to the nation of contributions to the store of natural knowledge. When they appreciate the fact that scientific work furnishes the motive power of industrial progress, they will regard it in a more serious and liberal spirit than at present. For this reason no opportunity should be lost of reminding the State of its duties and responsibilities as regards scientific work, the claims of which are not urged with sufficient force by the men engaged in it. Scientific societies and associations in Great Britain interest themselves in the advancement of natural knowledge, but it might be well occasionally to bold a meeting for the purpose of stating some of the relationships between research and national wellare. Such a meeting was held recently at Baltimore, by the American Society of Naturalists, and addresses on the attitude of the State toward scientific investigation were given by Prof. H. F. Osborn, Prof. W. Bullock Clark, Dr. L. O. Howard, Dr. B. T. Galloway and Prof. W. T Sedgwick. The following extracts from the remarks made upon this occasion are abridged from the report in Scientic.

In the course of the remarks with which the discussion was opened, Prnf. H. F. Osborn said :-

$A$ fair criterion of intelligence in the government of a country is afforded loy an examination of its annual budget. There is first the provision for a certain nuınher of expenditures which are purely conservative, because the State must maintain itself, it must defend itself, it must support a large class of office. holders who are more or less useful. These expenditures may be wisely and honestly made, but they largely go to waste; they are either immediately pruductive or altogether non-productive. On the other hand, there are expenditures in the nature of in vestments, looking to the future and characterising the most far-sighted statesmanship. Conspicuous among these are the funds invested in education and science.

Said Helmholt $z$ in 1862 : "In fact men of science form, as it were, an organised army, labouring on behalf of the whole nation, and generally under its direction and at its expense, to augment the stock of such knowledge as may serve to promote industrial enterprise, to increase wealth, to adorn life, to improve political and social relations, and to further the moral development of individual citizens. After the immediate practical results of their work we forbear to inquire; that we leave to the uninstructed. We are convinced that whatever contributes to the knowledge of the forces of nature or the powers of the human mind is worth cherishing, and may, in its own due time, bear practical fruit, very often where we should least have expected it."

Of Furopean countries Germany places in its budget the largest productive investments of this kind; France is not far behind, England is perhaps fourth and affords a conspicuous 
example of blindness and fatuity in the matter of unproductive investment; she has, it is true, established textile schools, but has not sufficiently supported technical schools; the cost of a single battleship would establish four splendidly equipped technical schools; England secures the ship and postpones the construction of the schools. All this is through no fault of her prophets of science, who have been as persistent as Jeremiah in foretelling the consequences which are sure to follow.

Yet England gave Darwin his schooling upon the Beagle; and Huxley secured his upon the Rattiesnake. As a seafaring nation, marine zoology appeals to her imagination, and the single notable departure from her short-sighted policy in the encouragement of pure science is the magnificent service she has rendered in the Challenger expedition. Our own Dana was trained upon the Wilkes expedition; the French Government equipped the Talisman; the German Government is supporting the highly successful cruise of the Valdivia and its publications under Chun; the U.S. Government has a perminent exploring vessel in the Albatross.

In this rivalry of foresightedness the German and French Governments have been our keenest competitors both on sea and land, and have probably surpassed us in the recognition of the ultimate economy of pure research. Germany's most admirable recent action is the subvention of Prof. Abbe for his investigations upon optics. Abbe's work was not in the nature of invention, but of research and discovery in the highest sense, resulting in the production of an illuminating stage, apochromatic and achromatic immersion lenses, which have fairly revolutionised biology. What we owe to these lenses in a theoretical sense could not be stated in a single volume, and the economic value is equally immeasurable.

The distinctive feature of pure science is that it is not remunerative; the practical rewards and returns are not the immediate objects in view. On the other hand, the work of Tyndall and Pasteur on fermentation, pursued in the first instance for its own sake, has come to have an economic importance which is simply incalculable.

American legislators have lent a willing ear to the advice of wise men. What we now enjoy we owe mainly to the counsels of Joseph Henry, Spencer F. Baird and G. Brown Goode. And I may call attention here to a thought which will be ex. panded presently, namely, that the secret of the success of these men is to be found in their enthusiasm, unselfishness and lofty scientific and personal character. When we consider the liberal appropriations made year after year for the United States Geological Survey, the nobly equipped station at Wood's Holl, the purely scientific work which is now being supported by many States and municipalities, there is abundant cause for congratulation. . . .

Prof. W. Bullock Clark dealt chiefly with the power of legislators, cooperation between national bureaux and University institutions and the preparation of men by universities for State work. He said :-

It nay perhaps be desirable to examine for a moment the reason why scientific investigation is not and cannot be selfsupporting. This may be found in the fact that the great majority of scientific researches have no immediate commercial value and as commodities cannot find a speedy or, in most instances probably, even a prospective market. We all know of many investigations, begun without thought of pecuniary advantage, that have ultimately produced practical results of the greatest importance. Instances might be cited of investigations the value of which were not apparent until a generation or more had passed, as, for example, palæontological researches which have laid the foundation for the correlation of deposits of great economic value. The support of such investigations must be looked upon as investments for the State which no far-sighted statesman will ignore.

We find that ever since the establishment of universities and seminaries widely over Europe in the fourteenth and fifteenth centuries, the civilised countries of the world have recognised in one form or another the relation of the State to scientific in. vestigation. Not only the great nations of the world, but oftentimes the small and relatively poor countries like Belgium and Switzerland, as well as the smallest of our own commonwealths, have frequently provided liberally for the support of scientific research. This has been accomplished through the publicly endowed educational institutions, through the public museums and through the special bureaux of the Government.

Too frequently scientific investigation has held a subordinate NO. 1632 , VOL. 63$]$ place in both the publicly and privately endowed institutions, their chief functions being either educational or commercial. The purpose of the schools and universities is primarily in most instances the instructing of youth in the already acquired results of scientific research rather than the fostering of investigation for itself, although the latter as a secondary consideration often holds a prominent place in the larger institutions of learning. The museums and scientific bureaux are, like our great universities, centres of research, without the exactions of teaching, where continuous investigation can bs pursued under most favourable conditions, although here again either educational or commercial considerations for the mnst part ostensibly control. That this is not always the case is cauce for congratulation, and the support of research directly for itself without.other, and oftentimes false, claims is b?coming yearly a more fully recognised fact.

It is interesting for u; who are Americans to know that the claims of science received recognition at the very inception of our Government, for we find that George Washington in his first message to Congress stated: "Nor am I less persuaded that you will agree with me in opinion that there is nothing more deserving your patronage than the promotion of science and literature. Knowledge in every country is the surest basis of public happiness In one in which the measures of government receive their inpressions so immediately from the sense of the community as ours it is proportionately essential." How well that early advice has been carried out by the statesmen of later days under the wise counsels of Henry, Baird, Goode and their successors, Prof. Osborn has already shown.

The various bureaux and division i f the U.S. Department of Agriculture, the U.S. Geological Survey and the U.S. Coast and Geodetic Survey are all manifesting a broad spirit of helpfulne ss that is being met by the St ite and university institutions. The possibilitie; of an extension of this co-operation between Nation, State and University promise well for the widening of the bounds of scientific investigation in this country. It is indeed a hopeful sign when we see the scientific men of the nation, whatever their affiliations, working together with mutual interest and respect. May it presage the dawn of a still brighter day in American science.

Dr. L. O. Howard spoke more particularly upon the ultimate practical importance of pure scientific work from the point of view of applied entomology, and the preparation of men for the scientific work of the State. He said :-

It is upon work in pure science that the entire superstructure of economic entomology has been built, and workers in applied science are constantly making use of the results of the labou's of workers in pure science. The practical outcome, however, of the labours of the workers in pure science is indirect, while the practical outcome of those who work in the economic applications of science is direct. In any emergency the direct method is the one which is immediately productive of practical results. The study of economic entomology is a study of facts which will enable us to meet one great and widely extended emergency. It must be conducted by the direct method, and the reason why this country stands in advance of the rest of the world in this application of science is because we are a practical people and have adopted the direct method. There can be no doubt, however, that it is necessary for the most successful economic worker to have had a sound training in pure science.

Men in charge of university departments of scientific work should keep closely in touch with the Government work along similar lines. They should be encouraged to do this by the Government. Government should employ their services wher ever they can be of use, and such cases are numerous. They themselves should be able, with the intimate knowledge acquired by official association or by close investigation of Government work, to lay out lines of study which will fit their students to take a hand in Government work. In many cases, of course, this cannot be thoroughly done in university laboratories at the present time.

The U.S. Department of Agriculture is the first of the Government bureaux which does economic zoological work. Good research work and initiative in investigation are encouraged. Nothing could be more ideally perfect than the relation between the present head of the Department of Agriculture and his scientific corps. Four years ago he announced his policy in this regard in conversation with one of his scientific chiefs in the following words:--." I am here to facilitate your work, not to dictate to you. Make your plans, conduct your investigations, 
and I will help you with all my strength, but I shall hold you responsible for results." Scientific men should honour James Wilson for the introduction of this novel principle in the administration of a Government scientific bureau ....

The old popular idea of a scientific man - that he lacks what is called "common sense," that he is unpractical-is an unfortunate estimate gained from unappreciative observation of workers in pure science, but it no longer, holds. Henry, Agassiz, Baird-all men of affairs, now gone-did much to change this popular estimate, and the host of brilliant men who have succeeded them-men of high scientific rank, who control the destinies and shape the policies of great institutions, and who turn out work of great and important practical value-have demonstrated beyond the slightest doulst that scientific men are the broadest men of affairs, that they are practical men, and that they are fit to be leaders, not only in thought, but in action.

It is doubtful whether any Government in existence does as much for the encouragement and development of science as does our own. This has repaid her a thousandfold, and the sound judgment of the American people and their patriotic pride in national attainment will effect a steady increase in governmental support of scientific work in spite of temporary checks. IVith scientific men, however, must come the initiative. They must point out the needs and the ways and means by which these needs must be supplied.

Dr. B. T. Galloway spoke as follows :-

Is it not true that the attitude of the State toward science and scientific research is at all times greatly influenced by the shaping of public sentiment through the work of scientific men themselves? This is a practical age, and in America especially the tendency is more and more to give a practical trend to almost every line of research. We find, therefore, as a matter of fact, that there is a general lack of interest in, and support of, matters having to do with pure science alone, while on the other hand all questions having practical application, and even those in which the practical end is remote, are received with commendable liberality. Taking the field of botany, for example, it would be difficult, if not impracticable, to secure support for the preparation and publication of purely foristic monographs, unless it could be pretty clearly shown that such a project had some practical end in view.

In so far, therefore, as the attitude of the State towards all work of this nature is concerned, there is a great deal of con servatism to be overcome, and this conservatism is especially pronounced where pure science is brought strongly to the front. The reason for this is not far to seck, for its roots lie imbedded in the selfishness of human nature, which, acting through organisation in the shape of government, sees, or thinks it sees, in the aggressiveness of science a menace to existing institutions in some form or other. While science in its nature is aggressive, the men who do most to advance it often lack aggressiveness, and for this reason the far-reaching effect of science as an educational factor at the present time is not fully understoud or appreciated.

This brings me more particularly to the main question I wish to raise in this discussion, namely, what should be the attitude of the scientific man toward the cause he represents. I am strongly of the opinion that he owes it to himself and to his work to put forth every legitimate effort to advance the interests of the cause. He should, of course, keep constantly before him the fact that to bring honour and credit to the work he must recognise the duties of life. This will not allow him, however, to sit calmly down and wait for the material things of the world to come to him. The men who have it in their power to aid him are too busy to go out of their way to render help unless that help is sought.

With the distinctly utilitarian sentiment towards science, as pointed out, the question arises as to what stand should be taken by those charged with the guidance of the work with respect to shaping a general pulicy which will meet the demand for practical ends, and at the s?me time advance the cause of science to the fullest extent. Extremes must be avoided, for if the tendency is too strong tuward pure science, opportunities will be lost through lack of support, and if toward ultrautilitarianism, science itself will be endangered through the development of false views, erroneous statements anil lack of judgment-rocks and reefs that must by all means be avoided. There is always a medium ground, however, where science and practice can each be made to help the other and each be the stronger for the support thus gained. This is the stand, I may say, that is now taken by those charged with most of the work conducted under the auspices of the Government, and which, during the past fifteen years at least, has resulted in a rapid development of all work along broad and safe lines. Most of the departments of the Government, wherein scientific work is carried on, owe their existence to a demand for greater know. ledge on problems concerning the interests and welfare of the people. In the early days of this work ton much attention was given to a mere diffusion of knowledge without regard to its source, and as a result of this original research did not receive the attention it deserved. In later years, however, the importance of research is becoming more and more appreciated, and as a result the work has increased in strength and now commands the respect it deserves. ...

Prof. W. T. Sedgwick referred to the attitude of the people toward scientific investigation, and the hindrance inflicted upon scientific research by the tariff uf.on the requisite books and instruments. He arded :-

I hase been very much interested to hear the quotation from the "Message of Washington " urging upon our people the importance of promoting scientific investigation and research. I believe that the American people are, in increasin' numiers, large-minded enough to look through and beyond the nearer every-day phenomena, and to realise that the promotion of dis. covery, no less than the promotion of learning, pays in every sense of the word. They perceive that it pays in the highest sense, in the enrichment of intellect and the cultivation of faculty. They perceive also that it pays in the utilitarian sense, in that it gives leadership among the nations of the earth in the applications of science which always follow hard upon the heels of discovery. Prof. Osborn has done well to point out that those nations which support research most liberally are those which are taking the lead in the industrial world to-day.

The barricr between pure and applied science is fading away, because they are constantly drawing nearer together and overgrowing one another. Pure science has given to applied science the fundamental elements of truth, perfection, knowledge and skill. Applied science, on the other hand, has developed so prodigiously as to react favourably upon pure science, furnishing for it rich sustenance and fertile soil in which it may flourish. An hour might well be spent in pointing out, not only the aid which pure science has given to applied science, but reciprocally the enormous development of pure science and scientific investi. gation wrought by applied science. It is one of the marvels of the day that many highly organised and differentiated industries, and even many of the coarser arts, find their narrow but suffi. cient basis of profit in the employment of the results of the latest and most advanced researches in pure science.

Our age has been called by one of the speakers who has preceded me a practical age, and so it is; but it is an age which has discovered in science the Promethean fire. The highest and truest utilitarianism of to-day is a generous cultivation of scientific investigation, not indeed for its own sake, but for the sake of the resulis which are sure to follow from it. As to the pursuit of science for its own sake, Prof. Osborn has, it seems to me, used a happy illustration in referring to the scientific inves tigations of the Government as an investment rather than an immediate outlay for current expenses. As to pure science pursued strictly for its own sake, I think we may rather describe it as an investment from which we still expect ulti mately some return. Science for its own sake is, a!ter all, much like investment for its own sake; which has never been made, I fancy, even by the least practical of philanthropists.

For illustration of public appreciation of scientific research as a necessity for practical results, I may give an example. When in 1886 the newly organised Siate Board of Health of Massa. chusetts attacked scientifically the problem of protection of the purity of inland waters, they reported to the people of that State that in order to do the work required by the Iegislature it would be necessary to inaugurate and prosecute special and novel investigations, and for this and other purposes they asked for an appropriation of 30,000 dollars. This sum was immediateiy and cheerfully granted by the people for this purpose and has ever since been continued, annually, with the result that the Massachusetts experiments are referred to with commendation and advantage by bacteriologists and engineers all over the world. Again, when it became clear that antitoxin for diphtheria had become a public necessity and its proper preparation a public duty, the same State Buard of II alth secured the services of one of the most distinguished 
bacteriologists in the country, Prof. Theobald Smith, and requested him, not only to prepare antitoxin for the citizens of the State, but also to investigate the best methods of its preparation and preservation, besides other cognate and novel but pressing problems in the field of pure science. Here also the most thorough-going utilitarianism has proved to be scientific investigation pushed to its utmost limits. . . .

\section{THE EFFECT OF PHYSICAL AGENTS ON $B A C T E R I A L$ LIFE.}

THE fact that life did not exist upon the earth at a remote period of time, the possibility of its present existence as well as the prospect of its ultimate extinction, can be traced to the operation of certain physical conditions. These physical conditions upon which the maintenance of life as a whole depends are in their main issues beyond the control of man. We can but study, predict and, it may be, utilise their effects for our benefit. Life in its individual manifestations is, therefore, conditioned by the physical environment in which it is placed. Life rests on a physical basis, and the main springs of its energies are derived from a larger world outside itself. If these conditions, physical or chemical, are favourable, the functions of life proceed; if unfavourable, they cease-and death ultimately ensues. These factors have been studied and their effects utilised to conserve health or to prevent disease. It is our purpose this evening to study some of the purely physical factors, not in their direct bearing on man, but in relation to much lower forms in the scale of life-forms which constitute in number a family far exceeding that of the human species, and of which we may produce at will in a test-tube, within a few hours, a population equal to that of London. These lowly forms of life-the bacteria-belong to the vegetable kingdom, and each individual is represented by a simple cell.

These forms of life are ubiquitous in the soil, air and water, and are likewise to be met with in intimate association with plants and animals, whose tissues they may likewise invade with injurious or deadly effects. Their study is commonly termed bacteriology - a term frequently regarded as synonymous with a branch of purely medical investigation. It would be a mistake, however, to suppose that bacteriology is solely concerned with the study of the germs of disease. The dangerous microbes are in a hopeless minority in comparison with the number of those which are continually performing varied and most useful functions in the economy of nature. Their wide importance is due to the fact that they ensure the resolution and redistribution of dead and effete organic matter which, if allowed to accumulate, would speedily render life impossible on the surface of the earth. If medicine ceased to regard the bacteria, their study would still remain of primary importance in relation to many industrial processes in which they play a vital part. It will be seen, therefore, that their biology presents many points of interest to scientific workers generally. Their study as factors that ultimately concern us really began with Pasteur's researches upon fermentation. The subject of this evening's discourse, the effect of physical agents on bacterial life, is important not merely as a purely biological question, though this phase is of considerable interest, but also on account of the facts I have already indicated, viz. that micro-organisms fulfil such an important function in the processes of nature, in industrial operations, and in connection with the health of man and animals. It depends largely on the physical conditions to be met with in nature whether the micro-organisms exercise their functions, and likewise whether they die or remain inactive. Further, the conditions favouring one organism may be fatal to another, or an adaptability may be brought about to unusual conditions for their life. To the technologist the effect of physical agents in this respect is of importance, as a knowledge of their mode of action will guide him to the means to be employed for utilising the micro-organisms to the best advantage in processes of fermentation. The subject is of peculiar interest to those who are engaged in combating disease, as a knowledge of the physical agents that favour or retard bacterial life will furnish indications for the preventive measures to be adopted. With a suitable soil and an adequate temperature the propagation of bacteria proceeds with great rapidity. If the primary conditions of soil and an adequate temperature are not

I Discourse delivered at the Royal Institution by Dr. Allan Macfadyen, Director of the Jenner Institute of Preventive Medicine.

No. 1632 , vOL. 637 present, the organisms will not multiply ; they remain quiescent or they die. The surface layers of the soil harbour the vast majority of the bacteria, and constitute the great storehouse in nature for these forms of life, They lessen in number in the deeper layers of the soil, and few or none are to be met with at a depth of 8-Io feet. As a matter of fact, the soil is a most efficient bacterial filter, and the majority of the bacteria are retained in its surface layers and are to be met with there. In the surface soil, most bacteria find the necessary physical conditions for their growth, and may be said to exist there under natural conditions. It is in the surface soil that their main scavenging functions are performed. In the deeper layers, the absence of air and the temperature conditions prove inimical to most forms.

Amongst pathogenic bacteria the organisms of lockjaw and of malignant œdema appear to be eminently inhabitants of the soil. As an indication of the richness of the surface soil in bacteria I may mention that I gramme of surface soil may contain from several hundred thousand to as many as several millions of bacteria. The air is poorest in bacteria. The favouring physical conditions to be met with in the soil are not present in the air. Though bacteria are to be met with in the air they are not multiplying forms, as is the case in the soil. The majority to be met with in air are derived from the soil. Their number lessens when the surface soil is moist, and it increases as the surface soil dries. In a dry season the number of air organisms will tend to increase.

Town air contains more bacteria than country air, whilst they become few and tend to disappear at high levels and on the sea. A shower of rain purifies the air greatly of bacteria. The organisms being, as I stated, mainly derived from the surface of the ground, their number mainly depends on the physical condition of the soil, and this depends on the weather. Bacteria cannot pass independently to the air, they are forcibly transferred to it with dust from various surfaces. The relative bacterial purity of the atmosphere is mainly, therefore, a question of dust. Even when found floating about in the air the bacteria are to be met with in much greater number in the dust that settles on exposed surfaces, e.g. floors, carpets, clothes and furniture. Through a process of sedimentation the lower layers of the air become richer in dust and bacteria, and any disturbance of dust will increase the number of bacteria in the air.

The simple act of breathing does not disseminate disease germs from a patient; it requires an act of coughing to carry them into the air with minute particles of moisture. From the earliest times great weight has been laid upon the danger of infection through air-borne contagia, and with the introduction of antiseptic surgery the endeavour was made to lessen this danger as much as possible by means of the carbolic spray, \&c. In the same connection numerous bacteriological examinations of air have been made with the view of arriving at results of hygienic value. The average number of micro-organisms present in the air is 500-1000 per I000 litres; of this number only 100-200 are bacteria, and they are almost entirely harmless forms. The organisms of suppuration have been detected in the air, and the tubercle bacillus in the dust adhering to the walls of rooms. Investigation has not, however, proved air to be one of the important channels of infection. The bactericidal action of sunlight, desiccation, and the diluting action of the atmosphere on noxious substances, will always greatly lessen the risk of direct aërial infection.

The physical agents that promote the passage of bacteria into the air are inimical to their vitality. Thus, the majority pass into the air, not from moist, but from dry surfaces, and the preliminary drying is injurious to a large number of bacteria. It follows that if the air is rendered dust-free, it is practically deprived of all the organisms it may contain. As regards enclosed spaces, the stilling of dust and more especially the disinfection of surfaces liable to breed dust or to harbour bacteria are more important points than air disinfection, and this fact has been recognised in modern surgery. In an investigation, in conjunction with $\mathrm{Mr}$. Lunt, an estimation was arrived at of the ratio existing between the number of dust particles and bacteria in the air. We used Dr. Aitken's Dust-counter, which not only renders the dust particles visible, but gives a means of counting them in a sample of air. In an open suburb of London we found 20,000 dust particles in I cubic centimetre of air; in a yard in the centre of London about 500,000. The dust contamination we found to be about 900 per cent. greater in the centre of London than in a quiet suburb. In the open air of 